\title{
Nam and Sang
}

\section{Clare Royall}

Last Night NAm had agreed to have children. His wife, Sang, thought he was at work right now. He was actually frantically searching Swan Street. In Fit of Clarity \#4 last week, Nam got a job at a call centre. Just for now. Maybe he'd move on to something he was interested in or good at later. He got the job so he could pay the bills. He started on Monday and had been working there for three days. However at 11 o'clock this Thursday morning, he rose calmly from his swivel chair and walked out of the door, into the lift, out into the lobby, out of the building and went to score. He didn't even bother to pick up his bag or the packed lunch that Sang had made him out of the office mini fridge.

Nam walked towards Prahran, and although he felt weary, he also felt so much rage. Rage at his wife for constantly being the shining light that illuminated all his flaws. He just wanted to be left alone. He wanted no responsibility and she kept dragging him into things he didn't want. He loved Sang, but even more so, he needed her. She was his rock, the only person who continually forgave him. She let him come home after nights spent god-knows-where. She would feed him and help him get clean. Sang would change his sheets when he lay in bed comatose for weeks, unable to stop sweating and shaking. Despite all this devotion, Sang did not love him. She cared for him and believed he could be the man she would eventually love as the father of her children. So she stayed and tried to clean him up and dust him off. To scorn him when she saw marks up his arms and praise him when he landed shit jobs in labouring or at a call centre. Sang was 36 and wanted children.

Last night he had sat at the kitchen table of their flat and she served dinner. To Nam it felt like they were playing grownups. Sang had asked him how his day was and what the new job was like. 
She had worn an apron. Nam felt embarrassed for her. He pitied her. The apron was a symbol of her need for domesticity, her need to nurture. And she was wasting it all on him.

She'd told him that night over dinner that she wanted a baby. She needed a baby. She needed the hole to be filled, the hole that could only be filled with a small warm bundle. He knew it was going to happen one day of course. He had always known. It was the reason she had stayed with him for so long. Sang however did not know that her husband could never give her this. And Nam had taken away any possibility of her ever being able to bear a child.

Somewhere in the first year of shared dirty needles and letting men fuck him to get the money to fill them, he had caught hepatitis.

In Fit of Clarity \#1 he had gone to a doctor. He'd told the doctor he needed help to get clean. The doctor had tested him for everything under the sun and referred him to a drug counsellor. The test for hepatitis had come back positive and Nam never saw the counsellor because nothing could quite numb the shock of contracting a deadly disease like more heroin.

At that point, he didn't tell Sang that she was most likely infected too. She was on the pill so they had never used condoms. It was her fault really, he had reasoned. She did not know about the nameless men and still didn't to this day; he felt guilt over that. God knows where she thought the money came from.

He had resolved to tell Sang about his disease in Fit of Clarity \#2. By then she was sure to have it. But she had been working two jobs to support them both and he couldn't bring himself to do it. Neither of them had shown signs of the disease yet. They could have years.

Fit of Clarity \#3 had coincided with Nam's 34th birthday. By that time Sang was also 34 and would have left him if she had known. So he didn't tell her. Again. 
But last night, when she told him that now was the time for her to finally have her baby, he had agreed. And now his time was up and Sang was going to stop taking those little pills. Nam really had to tell her tonight. Otherwise things would go too far and he would be bringing a very sick child into the world.

He ambled home just after 6:30 P.M, the time he would've come home if he had actually stayed at his new job. Sang mistook the tell tale dark shadows in his face as just a long day at the call centre. The shadows stretched low below his eyes and pooled into his cheeks. But Sang was so inspired by Nam's Fit of Clarity \#4 and his newfound employment that she was blinded. She smiled when she saw him and embraced him. He couldn't help but think that this may be the last time she would, but in the warm hold of the smack, he felt like it was going to be ok. He had let her down before and she had forgiven him. He could smell jasmine soap on her neck. She pulled back and held him back at an arm's length, beaming. She said she had cooked a special meal for him.

Nam looks across their little lounge and into the tiny kitchen where she has set the table. She has cut flowers from the courtyard and placed them in middle of the table. The napkins are folded in the shape of little swans. She has made sure she has picked out cutlery from the same set. She ushers him into the seat and then sits in his lap. Before he can speak she says she has something she needs to tell him. She tries to look ashamed but he can see glee creeping through. Sang tells him a month ago, unable to go any longer, she took herself off the pill. She says it is a blessing that he is now clean. She took a test this morning and she is expecting. 